\title{
CONCERNING FACTORS OF SOIL EROSION, WITH SPECIAL REFERENCE TO TROPICAL AREAS
}

Jan DE PLOEY

\section{INTRODUCTION}

In this paper attention is focussed on several aspects of mass wasting and rainwash in subhumid and humid tropical areas. First a review is made of opinions concerning the mechanics and the typology of landslides, in relation to distinct climatological and ecological conditions, including disturbances created by man. Several suggestions are put forward with respect to the regional assessment of the relative stability of slopes, taking into account the changing soil mechanical properties of regoliths.

Comments are given on the results of recent laboratory investigations concerning soil crusting, stemflow on grasses, runoff generation and the erodibility of stony topsoils. These data may enlighten surface hydrology and soil erosion in cleared tropical areas, farmland, grasslands and subhumid to semiarid environments.

\section{LANDSLIDES}

There are good reasons to stress the ambivalent role, both direct or indirect, of the vegetation in the triggering mechanisms of landslides. TRICART (1972) wrote "Landslides may occur under a cover of natural vegetation, but they are more common on cleared land". This thesis is corroborated by detailed surveys in the Uluguru Mountains in Tanzania (TEMPLE \& RAPP, 1972, and RAPP, 1974). A discussion of the origin of mass movements in the Serra do Mar of southern Brazil led to similar conclusions; MEIS \& SILVA (1968), also BIGARELLA (1975) claimed that deforestation by man is the main cause of catastrophic landslides and subsequent river floods. On the other hand USSELMANN (1968) noted the fact of frequent mass movements in the forested Colombian Andes. In Hong Kong SO (1971) found, analyzing more than 700 mass movements from the very rainy month of June 1966 , that nearly $35 \%$ of all slips occurred under woodland, although this occupied only $8,4 \%$ of the land area. CRUZ (1974) described the catastrophic planar slides in the Caraguatatuba area, part of the forested serra do Mar, north of Santos. For the Owen Stanley Mountains of
Papua, THOMAS (1974) mentions slump scars and slides occurring under an unbroken canopy of rain forest, on slopes of about $30^{\circ}$ over weathered schist. On the other hand BOS (1971) describes many shallow slidings and solifluction on poorly vegetated slopes of subhumid northwestern Tunisia.

With ZARUBA \& MENCL (1969) one is inclined to believe that woodland and forests inhibit shallow mass movements, sheet slides and microslumping, which are more characteristic of cleared slopes, dense grasslands and subhumid to semiarid areas with reduced vegetation. This may be due to the fact that root systems of trees drain, consolidate and detain soil horizons or debris mantles. It is also true that evapotranspiration reaches a maximum when the vegetation consist of trees (GEIGER, 1966): this factor of drainage would increase shear strengths within the regolith, but often catastrophic mass movements, e. g. huge planar slides, occur during a limited time-span consisting of several rainy days. The total effect of evapotranspiration during such days is fairly negligible because interception and attendant vaporization cause a compensating reduction in transpiration (GOODELL, 1963). Moreover, root mats facilitate the infiltration of rain water. This was clearly shown by odometer tests on finely rooted, loamy sand regolith material from Caraguatatuba (DE PLOEY \& CRUZ, 1979). Limited amounts of rootlets, up to $5 \%$, increase the values of $\mathrm{k}$, the permeability coefficient, 5 to 10 times, when $\mathrm{k}$ is of the order of $10^{-5}$ or $10^{-4} \mathrm{~cm} / \mathrm{s}$. Thus root mats promote the reduction of shear strengths within the subsoil, especially when torrential rains occur at the end of the rainy season. Planar slides on granitoid and gneissic rocks are often stripping off the bedrock. Shear planes are situated at the base of loamy sandy regoliths, with a maximum thickness of several meters. The slides occur after one, two or maximum three very rainy days, when water is storing above the bedrock. Therefore, it seems reasonable to suppose that $\mathrm{k}$, within the rooted regolith, amounts to $10^{-3}$ or $5.10^{-3} \mathrm{~cm} / \mathrm{s}$ (a vertical infiltration rate between about 80 and $430 \mathrm{~cm} /$ day). Measurements 
indicated that these $\mathrm{k}$ values are realistic for the regoliths of the sugar loafs and steep sloping "morros" of the Serra do Mar of Caraguatatuba. Here, slope angles vary between $20^{\circ}$ and more than $40^{\circ}$. This means that the minimum values of the hydraulic gradients on the slopes are of the order of 0.3 , thus, there must be, during the rainy seasons, an important throughflow in these regoliths which may result in the constitution of a water body in the footslope zones. Such throughflow may be accompanied by a selective eluviation of fines (clay) and their accumulation near the concave basal slope. Such a catenary evolution has already been described by RUXTON (1958) on inselberg slopes in Sudan. This scheme merits further field verification and geotechnical evaluation; it points to primary triggering mechanisms which may be situated in the footslope areas, where shear strengths may be lower.

Also problematic bearing capacity of regolith material under tall trees, several tens of $m$ high, which exert an appreciable supplementary load, several $\mathrm{kg} / \mathrm{cm} 2$, on a limited portion of the soil. In a soaked, loamy sandy regolith cohesion c' may be of the order of $100 \mathrm{~g} / \mathrm{cm} 2$ and the angle of internal friction $\varphi$ ' may drop to about $10^{\circ}$. Computations, made on the basis of the equation for the bearing capacity of shallow footings (TERZAGHI \& PECK, 1967, p.223), suggest that local shear failures may occur under trees which are $35 \mathrm{~m}$, or higher.

Infiltration is high in grasslands with dense root systems and this allows the concentration of water in the subsoil, at least at limited depths. The same effect results from infiltration favoured by desiccation structures, which develop during a dry season or dry periods in clayey, especially montmorillonitic or illitic, subsoils. This is true, of course, for adobe mantles in semiarid areas. Water may also concentrate on top of more clayey $\mathrm{Bt}$ horizons during rainy periods. All these circunstances promote shallow mass movements, soil creep, sheet slides and microslumping. It seems that these mass movements occur less frequently in subhumid savannah regions because soils there are less heavily structured and rather deep-rooted.

Runoff means drainage on slopes and therefore a reduction of the landslide potential, but local runoff generation often also means local infiltration and hence, a reduction of shear strengths. Water penetrates into the soil in footslope sections and on places where colluviations takes place, e.g. near the downslope edges of fields. Such phenomena, combined with the above mentionned conditions of infiltration, may explain why cleared land is susceptible to shal- low slides. Runoff and flow lines also converge toward gullies and tributary incisions, which are preferencial sites for elongate slides and mudflow tracks or debris flows, as P. Temple and A. Rapp showed in the Mgeta area, in Tanzania.

Footslope deposits are often poorly consolidated and basal segments may be quite susceptible to failure according to the undrained loading concept of HUTCHINSON \& BHANDARI (1971). This means that mass movements on and accumulation from the upslope (feeder) segments produce rapid loading on the lower-angle slope. This loading generates high pore-water pressures and these in turn can cause failures at very low angles.

There is strong evidence that the angle of internal friction $\varphi^{\prime}$ of plastic, loamy materials is negatively related to the plasticity index $\mathrm{I}_{p}=$ $\mathrm{w}_{1}-\mathrm{w}_{\mathrm{p}}$ (liquid limit - plastic limit) (TERZAGHI \& PECK, 1967; DE CLERCQ, 1972; CARSON, 1975 and DE PLOEY \& CRUZ, 1979). This negative relationship can be expressed by the general equation $\varphi^{\prime}=\mathrm{a} \cdot \mathrm{e}^{-\mathrm{b}} \cdot \mathrm{I}_{\mathrm{p}}$. These $I_{p}$ tests are simple, well standardized and time - independent. The latter is not true for shear strength measurements in the field which are always dependent upon local and changing hydrological conditions. Therefore, it has been suggested to use the $I_{p}$ index, within the scope of a regional survey, as a useful tool for landslide hazard assessment (DE PLOEY, 1981). Of course, this $I_{p}$ approach may be only part of a global survey, which includes mass movement mapping, hydrological observations and selected shear strength measurements.

Still there is the difficult problem of rockfall and rockslides, as connected with rock mass strength classification in the field. Interesting, in this respect, is the method proposed by SELBY (1980), whereby the rock mass strength class results from the sum of the weighted values determined for seven parameters: intact rock strength, weathering, spacing of joints, joint orientations, width of joints, continuity of joints, outflow of groundwater. Higher numbers then reflect greater mass strength. Stability may be low on sugar loafs and all steep slopes with the following rock mass characteristics: rocks with a low unconfined compressive strength; continuous, open joints, steeply dipping out of slopes, with a thick infill and much outflow of groundwater, Selby's method requires simple equipment: a tape measure, an inclinometer and a Schmidt Hammer device for rock strength measurements.

The stability problem of long medium to steep slopes, with a slope angle superior to $15^{\circ}$. 
and a regolith on bedrock, may be summarized as follows:

a) The regolith is composed of loamy sandy material with a permeability coeficiente $\mathrm{k}$, superior to $10^{-3} \mathrm{~cm} / \mathrm{s}$. The regolith, especially its base, will be soaked during heavy rainy days and therefore the limiting angle of slope may become inferior to the residual angle of internal friction $\varphi$ 'r, measured under drained conditions. Forested and cleared slopes are both susceptible to planar slidings. For reasons explained above one may suppose that forested land is even the most unstable.

b) The regolith is sandy loamy to loamy, with a $\mathrm{k}$ value inferior to $10^{-3} \mathrm{~cm} / \mathrm{s}$. $I_{p}$ values are greater and shear strengths lower than those of loamy sandy regoliths. Under subhumid to semiarid conditions there will be a tendency to shallow mass movements, sheet slides, microslumping; mass movements are promoted on these subsoils which are sensitive to structural changes (desiccation), which in turn favour rapid infiltration of rain water. Forested slopes will then be more stable than cleared land, except for the case when surficial drainage by runoff is important on cultivated slopes.

\section{RUNOFF GENERATION AND RAINWASH}

Among other factors, including of course rainfall characteristics, topsoil crusting plays a major role in runoff generation. Topsoil crusting itself depends largely on such microprocesses as the slaking of unstable aggregates, the swelling of expandible clays and the formation of a filtration pavement (BRYAN, 1973). Infiltration rates, during rainfall, are lowered in sandy topsoils by the effects of topsoil liquefaction (DE PLOEY, 1969, 1971). In Belgium it was found that the crustability of sandy and loamy topsoils is definitely negatively related to the values of the consistency index $\mathrm{C}_{5-10}$. This index is derived from the liquid limit curve. In fact $\mathrm{C}_{5-10}=$ $\mathrm{w}_{5}-\mathrm{w}_{10}$, in which $\mathrm{w}_{5}, \mathrm{w}_{10}$ are the water contents when the two sections of a pat of soil in the Casagrande cup touch each other over a distance of $1 \mathrm{~cm}$ after respectively 5 and 10 blows (DE PLOEY, 1979, and DE PLOEY \& MÜCHER, 1981). The fact is that relatively stable topsoils (with a low crustability) absorb more water, to lower their consistency and to become liquefied, than unstable topsoils. The validity of the consistency index $\mathrm{C}_{5-10}$ was checked in the field (DE SMET, 1979; MASSY, 1980 and DEWEVER, 1980). From observations in winter corn fields in the loamy areas of Central Belgium it was found that global crusting and subsequent wash and colluviation characterize topsoils with a value of $\mathrm{C}_{5-10}<2$. Less than $50 \%$ of the total surface of winter corn fields, having soils with $\mathrm{C}_{5-10}>3$, were sealed at the end of March. It was also shown that the consistency index is most closely related to the sum of the percentages of clay +5 times the organic matter content. Therefore, one may expect that the crustability of many tropical topsoils is fairly high because they have a rather low organic matter content.

$\mathrm{C}_{5-10}$ has the advantage of being simply derived from an Atterberg test and to be defined as a time-independent property of the topsoil material. Therefore it is thought to be a useful tool for regional surveys of runoff and soil erosion risk assessment (DE PLOEY, 1981).

Runoff generation can be promoted on slopes with a fairly contiguous stony cover because boulders and blocks concentrate rainwater on the limited uncovered areas (YAIR \& KLEIN, 1973 and YAIR \& LAVEE, 1976). This was made clear by measurements and experiments in arid region, but the process may be of importance in different tropical areas where topsoils are stony (exhumed stone-lines, lateritic debris etc.) The more rainwash concentrates coarse elements on a slope, like a lag deposit, the more runoff will be activated, until the maximum stone cover density is reached.

Runoff is stimulated by stemflow on trees but also by stemflow on grasses and similar plants, especially in steppe-like areas. This has been made clear by recent experiments and a stemflow formula (DE PLOEY, 1982). It is estimated that the minimum supply of stemflow, to the base of sods and tussocks, is $50 \%$ to $100 \%$ of the amount of rain which falls on the basal surface. Therefore it has been proposed that the probability of runoff generation would be proportional to the tussock density and to a socalled stemflow increment ratio $R_{\text {st }}$. The latter factor depends entirely upon the physiognomy of the sods (width, shape, slope, angle of leaves and stems etc.), which determines its capacity to drain intercepted water to the internodal base of the grasses or herbs. The stemflow effect can be counterbalanced by a relative greater infiltration capacity of the topsoil underneath the tussocks, where the soil may be less sealed; this point merits further investigation.

A review has been made of available infiltrometer data, resulting from both field and laboratory experiments and measurements, which relate the runoff threshold $T_{r}$ (duration of rainfall, in minutes, to start runoff) to rainfall intensity $I_{r}$, in $\mathrm{mm} / \mathrm{h}$. The data have been obtained on various sediments and soils, with a tex- 
tural composition extending from light loamy sands to heavy loams (KURON, 1960; DE PLOEY, 1967, 1969; YAIR \& KLEIN, 1973; DELWAULLE, 1973; MOEYERSONS, 1975; RICHTER, 1977; BRYAN, YAIR \& HODGES, 1978; POESEN, 1981 and oral communication and IMESON \& KWAAD, 1976). A plot on loglog paper shows that the minimum and maximum values of $T_{r}$, for a given $I_{r}$, correspond to the following equations:

$$
\begin{aligned}
& \log \mathrm{T}_{\mathrm{r}}-\min =2.78-1.4 \log \mathrm{I}_{\mathrm{r}}{ }^{(1)} \\
& \log \mathrm{T}_{\mathrm{r}}-\max =3.23-1.3 \log \mathrm{I}_{\mathrm{r}}{ }^{(2)}
\end{aligned}
$$

$T_{r}$ values are lower than foreseen by equation (1) when topsoils are gravelous or stony. For rainstorm with the folowing intensities $I_{r}$ the extreme runoff threshold values correspond to:

$I_{r}=50 \mathrm{~mm} / \mathrm{h} ; T_{r}$ between 2.5 and 10 minutes

$I_{r}=40 \mathrm{~mm} / \mathrm{h} ; T_{r}$ between 3.5 and 14 minutes

$I_{r}=30 \mathrm{~mm} / \mathrm{h} ; T_{r}$ betwwen 5 and 20 minutes

$I_{r}=20 \mathrm{~mm} / \mathrm{h} ; T_{r}$ between 9 and 34 minutes

$I_{r}=10 \mathrm{~mm} / \mathrm{h} ; T_{r}$ between 24 and 84 minutes

The frequency and duration of high intensity rainfall in Belgium, according to data of LAURANT (1976) is such that the conditions of equation (2) are fullfilled at least once a year. This will certainly be true for most humid and subhumid tropical areas where high intensity falls are more frequent and more prononunced than in the temperate belt. Thus a safe conclusion is that the great majority of slopes in the tropical areas, which are not under forest, are affected by rainwash at least once a year. This conclusion may not be valid for pure sandy soils, but loamy subsoils are the most represented in the tropical belt, with many regoliths and surficial deposits derived from the Precambrian basement, limestones and volcanic rocks. According to the analysis of rainfall frequencies for the Persian Gulf coast of Iran (KAPPUS, BLEEK \& BLAIR, 1978), one may conclude that the abovementionned runoff thresholds occur, in semiarid areas, with a return period of maximum 2 years. Finally there is good reason to believe that most cleared land in the tropical and subtropical regions is eroded by heavy sheet (and rill) wash at least once a year.

The work done by ROOSE $(1975,1976$, 1977 ) on soil erosion in Ivory Coast is impor- tant. His conclusion is that Wischmeier's Universal Soil Loss Equation seems to be applicable to African soils poor in swelling clays. According to this author the most important factor modifying the potential erosivity of the rain is the green cover (importance of natural mulching), then the slope, then the soil type and finally the soil conservation practices. From measurements he concluded that many ferrallitic soils and ferruginous tropical soils, especially if they are gravelous, seem to be less erodible than a large number of leached topsoils of temperate regions. He suggested that soil conservation politics in areas with poor extensive agriculture would be based on the use of pure biological methods rather than on the introduction of sophisticated and expensive techniques like artificial mulching and terracing. This point of view fits in well with earlier considerations on soil water conservation policies formulated for Tanzania by TEMPLE (1972).

Of course the most catastrophic effect of rainwash is gullying and the extension of badlands. Extensive literature has reviewed these phenomena, marked by regional names such as the "lavaka" of Madagascar (RIQUIER, 1958 and HURAULT, 1971) and the "boçorocas"' of southern Brazil (PRANDINI, 1974 and QUEIROZ NETO, 1975). Several distinct processes seem to favour the development of gullies.

1) The destruction of the vegetation and the compaction of the topsoil on roads and tracks; a) tracks in the forest, e. g. in the Tijuca National Park near Rio de Janeiro (COELHO NETTO, 1979) b) tracks in suburban and urban areas, e. g. in West and Central Africa (MICHEL, 1975 and LUTUMBA, 1975) c) cattle and game tracks (BISHOP, 1962 and ALEXANDRE PYRE, 1975).

2) The destruction of drainage systems along roads and streets when underestimated "flash floods" occur.

3) Major triggering process in many areas seems to be piping as it was shown in Tunisia and in Zimbabwe (DE PLOEY, 1973 and STOCKING, 1980). Pipeflow becomes possible in many plastic soils which are characterized by desiccation cracks and blocky, prismatic or columnar structures. Piping head cuts retreat, deepen and become finally gully heads.

4) Slides in talweg zones.

5) In many areas rills are reported to occur on slopes that are equal to or steeper than $2^{\circ}$ to $3^{\circ}$, on mainly loamy or loamy-sandy soils, and laboratory experiments show the same limits, irrespective what the unit-discharge is (SAVAT \& DE PLOEY, 1982). It was shown that the on- 
set of rills is related to the competence of the flow, which is mainly a function of Slope and Froude Number. It is still an open question if and when rills evolve into gullies by overland flow (without intervention of piping). It seems, acoording to the review written by J. Savat and J. De Ploey, that gullying, issuing from surface flow, often starts on slopes of $12^{\circ}-16^{\circ}$ but the reason for this is unknown.

The protective effects of the vegetation and of the stony pavements should not be overestimated. There is the above mentionned stemflow process and the fact that trees act as sprinklers, which realese the coarsest 4-6 mm drops, dripping from the foliage after interception. The erosive power of runoff can also be increased by obstacles, like stones and sods on medium to steep slopes, because obstacles create turbulence and provoke vortex erosion (DE PLOEY, SAVAT \& MOEYERSONS, 1976). Experiments proved that wash on a vegetated slope can be superior to erosion on a bare soil.
More attention will have to be paid to the combination of wash and wind erosion. Material redeposited by water often shows a granuloclassification and this promotes selective deflation. There is also the question of increasing wind erosion on arable land with shallow, humic topsoils. It is one of the aspects of progressive desertization, as described for Africa by RAPP (1974).

Finally it has to be mentionned that in many areas valley-bottoms have been coreved by important colluvial deposits, resulting from increased slope wash on cleared land. Often these colluvia are relatively fertile and they need conservation measures. One of the problems is that they become eroded by gullying because, after deforestation, runoff yields increased tremendously and pipeflow became active. In the Gongola besin, in northeastern Nigeria, it was shown that gullies evolved into $100-300 \mathrm{~m}$ large arroyos during the last few decades (VAN NOTEN \& DE PLOEY, 1977).

\section{BIBLIOGRAPHY}

ALEXANDRE-PYRE, S. - 1975 - Études d'évolution des ravinements sur les plateaux sableux du Haut Shaba. In "Géomorphologie Dynamique dans les régions intertropicales" J. Alexandre coord., Presses Universitaires du Zaire, pp 155-160

BIGARELLA, J.J. - 1975 - Topics for discussion. In Intern. Symp. Quaternary, Bol. Paranaense Geoc., 370 p

BISHOP, W.W. - $1962-$ Gully erosion in the Queen Elizabeth National Park. Uganda Journ. 26 (2): 161-165

BOS, R.H.G. - 1971 - Quaternary evolution of a mountanious area in NW Tunisia. A geomorphological and pedological analysis. Publ. Fysisch - geografisch en bodemkundig Labor. Univ. Amsterdam, 19, 167 p

BRYAN, R.B. - 1973 - Surface crusts formed under simulated rainfall on Canadian soils. Consiglio Nazion. delle Richerche, Labor. per la Chimica del terreno, Pisa Confer., 2, pp 3-30

BRYAN, R.B.; YAIR, A. \& HODGES, W. 1978 - Factors controlling the initiation of runoff and piping in Dinosaur Provincial Park badlands, Alberta, Canada. Zeits. Geomorph., Suppl. Band 29, pp 151-168

CARSON, M.A. - 1975 - Treshold and characteristic angles of straight slopes. In Mass Wasting, 4th Guelph Symp. Geomorph., p 19-34

COELHO NETO, A.L. - $1979-$ O processo erosivo nas encostas do maçiço da Tijuca, Rio de Janeiro. Tese de mestrado, Inst. Geoc. Univ. Fed. R. de Janeiro

CRUZ, O. - 1974 - A serra do Mar e o litoral na área de Caraguatatuba, SP: contribuição à geomorfologia litorânea tropical. Série Teses e Monografias, IGEOG - USP, 11, 181 $\mathrm{pp}$

DE CLERCQ, A. - 1972 - Parameter onder zoek betreffende grondverschuvingen op Yperiaan en Paniseliaan substraat. M.SC. Thesis Univer. Leuven

DELWAULLE, J.C. - 1973 - Resultats de six ans d'observations sur lérosin au Niger. Rev. Bois et Forets des Tropiques, 150:15-36

DE PLOEY, J. - 1967 - Érosion pluviale au Congo ocidentale. In "Isotopes in Hydrology", IAEA, 291-301, Viena

1969 - L'érosion pluviale: expérimentations à l'aide des sables traceurs et bilans morphogéniques. Acta Geogr. Lovaniense (7): $1-28$

1971 - Liquefaction and rainwash erosion. Zeits. Geomorph., 15(4):491-496

1973 - Ruisselement diffus, ravinements et badlands dans le bassin de Kasserine (Tunisie Steppique). Ann. Mines et Géologie, Tunis, (26): 583-593

1979 - A consistency index and the prediction of surface crusting on Belgian loamy soils. Colloque Érosion Agricole des 
sols en millieu temperé non mediterranéen, Strasbourg, Comptes Rend., pp 133-137

DE PLOEY, J. - 1981 - Crusting and timedependent rainwash mechanisms on loamy soils. In "Soil conservation, problems and prospects", R.P.C. Morgan (Edit.), p. 139-152, Chichester

1982 - A stemflow equation for gras-

ses and similar vegetation. Catena 9:139-152

\& CRUZ, O. - 1979 - Landslides in

the serra do Mar, Brazil, Catena, 6:111-122

\& MÜCHER, H.J. - 1981 - A con-

sistency index and rainwash mechanism on Belgian loamy soils. Earth Surf. Processes, 6:319-330

, SAVAT, J. \& MOEYERSONS, J. 1976 - The differential impact of some soil loss factors on flow, runoff creep and rainwash. Earth Surf. Processes, 1:151-161

DE SMET, C. - 1979 - Een consistentie index en experimenten betteffende verslemping op lemige akkers. M. Sci. Thesis, Univ. Leuven

DEWEVER, J. - 1980 - De consistentie-index erosivieverschijnselen op zandige tot lemige akkers. Thesis, Univ. Leuven

GEIGER, R. - 1966 - The climate near the ground. Harvard Univ. Press, $611 \mathrm{p}$

GOODELL, B.C. - 1963 - A reappraisal of precipitation interception by plants and attendant water loss. Journ. Soil Water Conserv, 22:231-234

HURAULT, J. - 1971 - La signification morphologique des lavakas, Rév. Géomorph. Dynamique, 20:121-128

HUTCHINSON, J.N. \& BHANDARI, R.K. 1971 - Undrained loading, a fundamental mechanism of mudflows and other mass movements. Géotechnique, 21:353-358

IMESON, A.C. \& KWAAD, F. - 1976 - Some effects of burrowing animals on slope processes in the Luxembourg Ardènnes. Gégr. Annaler 58, Sér. A, pp. 317-328

KAPPUS, U., BLEEK, J.M. BLAIR, S. H. 1978 - Rainfall frequencies for the Persian Gulf Coast of Iran. Hydrological Sciences Bull., 23(1):119-129

KURON, H. - 1960 - Long-term measurements of runoff and soil loss on three typical soils of Germany. Publ. IAHS $53: 135-142$

LAURANT, A. - 1976 - Nouvelles récherches sur les intensités maximuns de précipitations à Uccle. Courbes d'intensité-durée-fréquence. Ann. Travaux Publ. Belgique, 4:320-328

LUTUMBA, I. 1975 - L'érosion dans la ville de Bukavu. In "Géomorphologie dynamique dans les régions intertropicales", J. Alexan- dre coord, Presses Universitaires Zaire, pp 221-228

MASSY, M. - $1980-$ Bijdrage tot het onderz oek van verslemping en geulerosie op akkers. M. Scienc. Thesis, Univer. Leuven

MEIS, M. R. M. \& SILVA, J.X. - $1968-$ Mouvements de masse recentes a Rio de Janeiro. Une étude de géomophologie dynamique. Rév. Géomorph. Dynam., $18: 145-152$

MICHEL, P. - 1975 - La dynamique actuelle de la géomorphologie dans le domaine soudanien de l'ouest africain: examples du Mali Occidental et Senegal Oriental. In "Géomorphologie dynamique dans les regions tropicales'. J Alexandre coord., Presses Univ. Zaire, pp 1-20

MOEYERSONS, J. - 1975 - An experimental study of pluvial processes on granite gruss. Catena 2:289-308

POESEN, J. - 1981 - Rainwash experiments on the erodibility of loose sediments. Earth Surf. Sedim., 6:285-307

PRANDINI, F.L. - 1974 - Occurrence of boçorocas in southern Brazil: geological conditioning of environmental degradation. Proc. II Intern. Congr. Assoc. Eng. Geol., 1(3):1-36

QUEIROZ NETO, J.P. - 1975 - Les problèmes de l'érosion accelerée dans l'État de São Paulo, Brésil. In "Geomorphologie Dynamique dans les régions intertropicales", $\mathrm{J}$. Alexandre coord. Presses Univers. Zaire, pp $205-220$

RAPP, A. 1974 - A review of desertization in Africa. SIES, Stockholm, report no 1

RICHTER, G. 1977 - Bibliographie zur Bodenerosion und Bodenerhaltung 1965 - 1975. Forschungsstelle Bodenerosion der Univ. Trier, 2, $97 \mathrm{p}$

RIQUIER, J. - 1958 - Les lavakas de Madagascar. Bull. Soc. Géogr. de Marseilles 69:181-191

ROOSE, E.J. - 1975 - Natural mulch or chemicalconditioners for reducing soil erosion in humid tropical areas. Soil Conditioners, Spec. Publ. (7), Soil Scien. Soc. America, 131-138

1976 - Use of the Universal Soil Loss Equation to predict erosion in West Africa. In "Soil Erosion: prediction and control.", Soil Scien. Soc. America (Edit), Spec. publ. 21:60-74

1977 - Adaptation of soil conservation techniques to the ecological and socioeconomic conditions of West Africa. Agron. Trop. 32(2):132-140 
RUXTON, B.P. - 1958 - Weathering and subsurface erosion in granite at the piedmont Angle, Balos, Sudan. Geolog. Magaz., 95: 353-377

SAVAT, J. \& DE PLOEY, J. 1982 - Sheetwash and rill development by surface flow. In "Badland Geomorphologie and piping", R. Bryan \& A. Yair, Edits., Geo-books, pp 113-126

SELBY, M.J. - 1980 - A rock mass strength classification for geomorphic purposes: with tests from Antarctica and New Zealand. Zeitsch. Geomorph., 24(1):31-51

SO, C.L. - 1971 - Mass movements associated with the rainstorm of June 1966 in Hong Kong. Trans. Inst. Br. Geogr., 53:55-66

STOCKING, M.A. - 1980 - Examination of the factors controlling gully growth. In "Assessment of Erosion", M. De Boodt and D. Gabriels (Edits.), Willey, pp 505-520

TEMPLE, P.H. - 1972 - Studies of soil erosion and sedimentation in Tanzania. Geogr. Ann., 54 A, 34:110-124

\& RAPP, A. - 1972 - Landslides in the Mgeta area, Western Uluguru Mountains. Tanz. Geogr. Ann., 54 A:157-194
TERZAGHI, K. \& PECK, R.B. - 1967 - Soil Mechanics in Engineering Practice. Willey, $729 \mathrm{p}$

THOMAS, M.F. - 1974 - Tropical Geomorphology, Macmillan, $322 \mathrm{p}$.

TRICART, J. - 1972 - Landforms of the humid tropics, forests and savannas. Longman, 306 p, London

USSELMANN, P. - 1968 - Discussion of M.R.M. de Meis and J.X. da Silva: "Mouvements de masse récentes a Rio de Janeiro - Une étude de géomorphologie dynamique'’. Rév. Géomorph. Dynam. 18(4):1-15

VAN NOTEN, F. \& DE PLOEY, J. - 1977 - Quaternary research in northeastern Nigeria. Ann. Mus. Central Africa, 92, 61 p, Tervuren

YAIR, A. \& KLEIN, M. - 1973 - The influence of surface properties on flow and erosion processes on debris covered slopes in an arid area. Catena 1:1-18

\& LAVEE, H. - 1976 - Runnof generation processes and runoff yield from talus mantle slopes. Earth Surface Processes, $1: 235-247$

ZARUBA, Q. \& MENCL, V. - 1969 - Landslides and their control. Elsevier, 205 p, Amsterdam

Trabalho apresentado na Seção principal da "Latin American Regional Conference" - IGU - Rio de Janeiro - 1982, vol. II - Simpósios e Mesas-Redondas, p. 317-322, IBGE - Rio de Janeiro.

Endereço do autor:

Jan De Ploey - Laboratorium voor Experimentele Geomorfologie, Instituut voor Aardewetenschappen, Redingenstraat 14 bis, B-3.000, Leuven, Belgium. 